\title{
Dopaminergic Regulation of the Serotonergic Raphe-Striatal Pathway: Microdialysis Studies in Freely Moving Rats
}

\author{
Sergi Ferré, Roser Cortés, and Francesc Artigas \\ Department of Neurochemistry, Centro de Investigación y Desarrollo, C.S.I.C., 08034 Barcelona, Spain
}

\begin{abstract}
Morphological evidence demonstrates the existence of dopaminergic afferent pathways and dopamine (DA)-containing neurons in the dorsal raphe nucleus (DRN). In a recent report, a $D A D_{2}$-like receptor-mediated regulation of serotonin (5-HT) extracellular concentration in DRN has been found. Given the existence of somatodendritic 5-HT ${ }_{1 \mathrm{~A}}$ autoreceptors in the DRN, changes of the extracellular concentration of 5-HT in the vicinity of cell bodies and dendrites may be relevant for the control of the activity of ascending serotonergic pathways. In the present brain microdialysis study we have used a chromatographic method (HPLC) enabling the simultaneous measurement of DA, 5-HT, and their main metabolites dihydroxyphenylacetic acid (DOPAC) and 5-hydroxyindoleacetic acid (5-HIAA). The presence of a neuronal pool of DA within the DRN was revealed by the local infusion of amphetamine $(10 \mu \mathrm{M})$, which significantly increased the extracellular concentration of both amines. The local striatal infusion (10 $\mu \mathrm{M})$ of the selective DA $D_{1}$-like agonist SKF-38393, the selective $D A D_{2}$-like agonist quinpirole (LY 171,555), or the nonselective DA agonist apomorphine markedly decreased DA and DOPAC extracellular concentrations and failed to modify 5-HT or 5-HIAA in the striatum, indicating the lack of terminal (striatal) control of 5-HT release by dopaminergic transmission. In contrast, the systemic administration of apomorphine $(2.8 \mu \mathrm{mol} / \mathrm{kg}, \mathrm{s.c}$.) significantly increased the extracellular concentration of 5-HT in the DRN and decreased it in the striatum. The reduction of striatal $5-\mathrm{HT}$ extracellular concentration was prevented by the previous administration of the selective $5-\mathrm{HT}_{1 \mathrm{~A}}$ receptor antagonist WAY 100135 (17.6 $\mu \mathrm{mol} / \mathrm{kg}$, s.c.), which by itself did not change extracellular $5-\mathrm{HT}$ in striatum. These results support that dopaminergic neurotransmission inhibits the activity of DRN-striatal neurons by increasing 5-HT extracellular concentration in DRN and, consequently, by increasing somatodendritic $5-\mathrm{HT}_{1 \mathrm{~A}}$ autoreceptor stimulation in this nucleus.
\end{abstract}

IKey words: dorsal raphe nucleus, striatum, serotonin, dopamine, dopamine $D_{1}$-like receptors, dopamine $D_{2}$-like receptors, serotonin 5-HT ${ }_{1 A}$ receptors, in vivo microdialysis]

\footnotetext{
Received Sept. 30, 1993; revised Jan. 25, 1994; accepted Feb. 8, 1994.

This work was supported by grants from the Fondo de Investigacion Sanitaria (FIS 92/0268) and the EEC (STEP contract CT91-005). We gratefully acknowledge the technical assistance of Josefa Torres and Letizia Campa. We thank Wyeth Research UK (Maidenhead, UK) for the supply of WAY 100135. Citalopram was a generous gift of Lundbeck (Copenhagen, DK)

Correspondence should be addressed to Dr. Francesc Artigas, Department of Neurochemistry, C.S.I.C., Jordi Girona 18-26, E-08034 Barcelona.

Copyright (C) 1994 Society for Neuroscience $0270-6474 / 94 / 144839-08 \$ 05.00 / 0$
}

The dorsal raphe nucleus (DRN) (B6 and B7 areas of Dahlström and Fuxe, 1964) is a morphologically well-defined structure of the midbrain that contains, by far, the highest number and concentration of serotonergic (5-HT) cell bodies of the mammalian brain (Wiklund et al., 1981; Descarries et al., 1982). Serotonergic neurons from the dorsal raphe project mainly to the basal ganglia, particularly the striatum (dorsal and ventral), the substantia nigra (SN), and the ventral tegmental area (VTA) (A9 and A10 areas of Dahlström and Fuxe, 1964) (Van der Kooy and Hattori, 1980; Herve et al., 1987), and to the frontal cortex (O'Hearn and Molliver, 1984). These areas are involved in the parallel processing of motor function (Alexander and Crutcher, 1990) and are the source of and targets for the mesencephalic dopaminergic systems (Björklund and Lindvall, 1984). These morphological data suggest that DRN serotonergic neurons modulate the function of brain dopaminergic systems. Indeed, dopamine (DA)-containing structures display moderate to high densities of several $5-\mathrm{HT}$ receptor subtypes $\left(5-\mathrm{HT}_{1 \mathrm{~B} / \mathrm{DD}}\right.$, 5-HT $2,5-\mathrm{HT}_{3}$ ) (Pazos and Palacios, 1985; Pazos et al., 1985; Waeber et al., 1989, 1990; Hoyer, 1990) and there is functional evidence of a 5-HT-mediated regulation of mesencephalic dopaminergic systems, both at the somatodendritic (Nedergaard et al., 1988; Guan and McBride, 1989) and at the terminal level (Blandina et al., 1989; Benloucif and Galloway, 1991; Chen et al., 1991; Parsons and Justice, 1993).

Less is known, however, about a possible dopaminergic regulation of serotonergic DRN neurons, despite morphological evidence indicating the existence of projections from $\mathrm{SN}$ and VTA to the DRN (Afifi and Kaelber, 1965; Pasquier et al., 1977; Sakai et al., 1977; Lee and Geyer, 1984; Kalén et al., 1988) and of DA-containing neurons within the DRN (Hökfelt et al., 1976; Geffard et al., 1987; Kalén et al., 1988). Also, the DRN contains a fairly high density of DA D,-like but not of DA $D_{1}$-like receptors (Bouthenet et al., 1987; Palacios and Pazos, 1987). Furthermore, electrophysiological studies have shown that the electrical stimulation of SN induces cessation of firing of DRN neurons (Stern et al., 1981; for review, sce Aghajanian et al., 1987; Jacobs and Azmitia, 1992).

The study of the complex interrelationships between both aminergic systems is relevant for understanding the serotonergic changes occurring in neurological diseases where DA is the transmitter primarily involved (e.g., Parkinson's disease) (Scatton et al., 1984; Cross, 1988). Besides, DA-5-HT interactions are thought to play a role in the mechanism of action of atypical neuroleptics (Tamminga and Gerlach, 1987; Meltzer, 1992) and dopaminergic transmission appears to participate in the 3,4methylenedioxyamphetamine (MDMA)-induced degeneration of serotonergic terminals (see McKenna and Peroutka, 1990, 

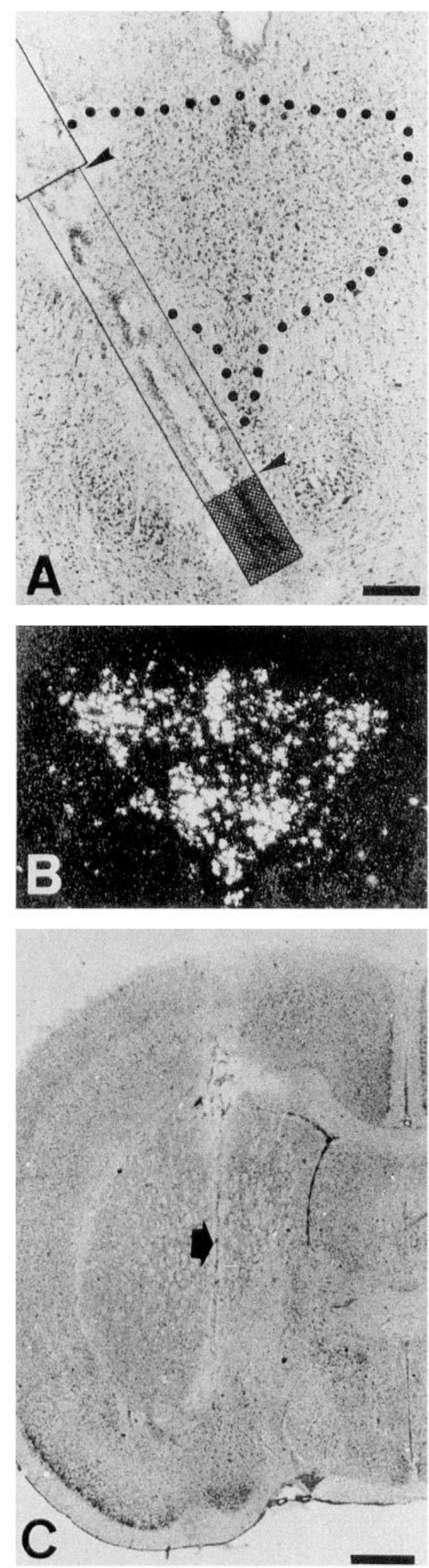

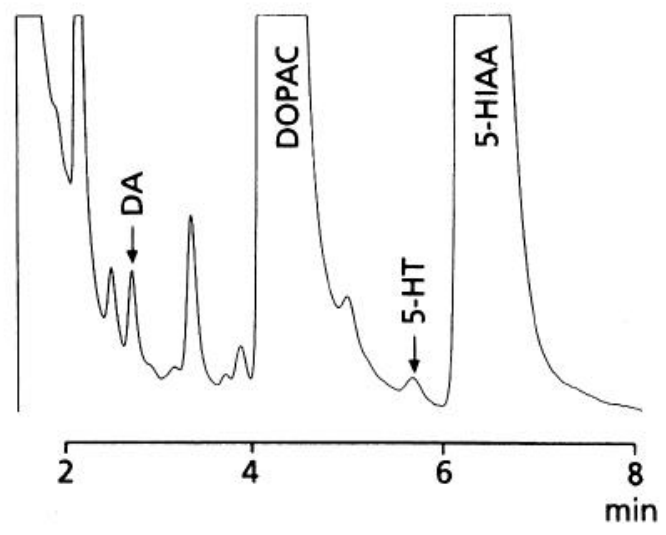

Figure 2. HPLC trace of a basal (predrug) striatal dialysate sample showing the presence of DA, DOPAC, 5-HT, and 5-HIAA. Absolute amounts of these compounds in this sample $(15 \mu \mathrm{l})$ of DA, DOPAC, 5 -HT, and 5-HIAA were (in fmol) $175,185,225,16$, and 22,560, respectively.

for review). Using the microdialysis technique, we recently found a DA $D_{2}$-like receptor-mediated regulation of 5-HT extracellular concentration in the DRN of unanesthetized rats. Local infusion of the nonselective DA receptor agonist apomorphine or the selective $\mathrm{DA}_{2}$-like receptor agonist quinpirole induced an increase of extracellular 5-HT in the DRN that was antagonized by the DA $D_{2}$-like receptor antagonist raclopride, but not by the DA $D_{1}$-like antagonist SCH 23390 (Ferre and Artigas, 1993). The existence of somatodendritic 5-HT $\mathrm{T}_{1 \mathrm{~A}}$ autoreceptors that inhibit electrical activity (Sprouse and Aghajanian, 1987. 1988), 5-HT synthesis (Hjorth and Magnusson, 1988; Hutson et al., 1989; Invernizzi et al., 1991), and 5-HT release in projection areas (Hutson et al., 1989: Sharp et al., 1989a; Bonvento et al., 1992; Adell et al., 1993) is well documented (Pazos and Palacios, 1985; Vergé et al., 1986; Sotelo et al., 1990). Therefore, an increased dopaminergic transmission within the DRN may inhibit the activity of ascending DRN serotonergic neurons through an enhancement of 5-HT extracellular concentration in DRN and further activation of 5-HT $\mathrm{HA}_{\mathrm{A}}$ autoreceptors. Indeed, pharmacologically induced increases of extracellular 5-HT in the raphe nuclei reduce terminal 5-HT synthesis and/or release, as measured with the push-pull cannula in the cat (Becquet et al., 1990) or in vivo microdialysis in awake, freely moving rats (Adell and Artigas, 1991).

In the present study, we have examined the effects of dopaminergic agents on extracellular 5-HT in the DRN and DA and $5-\mathrm{HT}$ in the striatum. The data obtained support the view that

Figure 1 . Location of the dialysis probes. $A$. Photomicrograph from a cresyl violet-stained section through the DRN (area delimited by dots) showing the track left by the microdialysis probe. The schematic drawing of the probe represents its actual size and position. The dialysis membrane corresponds to the part between arrowheads and the crosshatched area is the tip of the probe (epoxy resin). B. Dark-field photomicrograph from an autoradiogram of the DRN at a level similar to that in $A$. Serotonergic cell bodies have been labeled with a ${ }^{35} \mathrm{~S}$-oligonucleotide directed against the 5-HT transporter mRNA by in situ hybridization as described elsewhere (Cortés et al., 1993). C. Section through the striatum showing the track left by the microdialysis membrane (arrow). Scale bar: $250 \mu \mathrm{m}$ for $A$ and $B, 1 \mathrm{~mm}$ for $C$. 
an increased dopaminergic activity results in opposite changes of extracellular 5-HT in DRN and striatum.

\section{Materials and Methods}

Animals. Male Wistar rats weighing $290-310 \mathrm{gm}$ were used. They were housed four per cage and kept in a controlled environment $(12 \mathrm{hr}$ light/ dark cycle and $22 \pm 2^{\circ} \mathrm{C}$ room temperature). Food and water were provided ad libitum. Animal care followed the Spanish legislation on "Protection of Animals Used in Experimental and Other Scientific Purposes," in agreement with the European (E.E.C.) regulations (O.J. of E.C. L358/1 18/12/1986).

Surgerv. Concentric dialysis probes were made as previously described (Adell and Artigas, 1991), with the exception that the length of the membrane exposed to the brain tissue was either $1.5 \mathrm{~mm}$ or 4.0 $\mathrm{mm}$ long $(0.25 \mathrm{~mm}$ o.d.). Before implantation, rats were anesthetized with sodium pentobarbital $(60 \mathrm{mg} / \mathrm{kg}$, i.p.) and placed in a stereotaxic frame. Dialysis probes $(1.5 \mathrm{~mm})$ were implanted in the DRN with a lateral angle of $30^{\circ}$ and the following coordinates, in millimeters, with respect to bregma: AP - 7.8, L 3.1, D - 7.5 (Paxinos and Watson, 1982). Dialysis $(4 \mathrm{~mm})$ probes were implanted in the striatum with the following coordinates, in millimeters, with respect to bregma: AP $0.2, \mathrm{~L}$ 3.0, D -8.0 (Paxinos and Watson, 1982). The location of the dialysis probes is shown in Figure 1.

Microdialysis procedure. Animals were allowed to recover from surgery for approximately $18-20 \mathrm{hr}$ and then probes were perfused with artificial cerebrospinal fluid $(125 \mathrm{~mm} \mathrm{NaCl}, 2.5 \mathrm{~mm} \mathrm{KCl}, 1.26 \mathrm{~mm}$ $\mathrm{CaCl}_{2}$, and $\left.1.18 \mathrm{mM} \mathrm{MgCl}_{2} ; \mathrm{pH} 6.2\right)$ at $0.5 \mu \mathrm{l} / \mathrm{min}$ using a $\mathrm{CMA} / 100$ microinjection pump (Carnegie Medicin, Stockholm, Sweden). Sample collection started $60 \mathrm{~min}$ after the beginning of perfusion. Usually four or five basal fractions were collected to obtain basal values before either local infusion or systemic administration of drugs. Local administration was performed by reverse dialysis, dissolving the appropriate amounts of each drug in the perfusion fluid. Systemic administrations were carried out subcutaneously using $5.5 \%$ glucose as vehicle (injection volume of $2 \mathrm{ml} / \mathrm{kg}$ ). The effects of systemic apomorphine on extracellular 5-HT in DRN and striatum were performed in separate groups of rats. Given the small size of the $1.5 \mathrm{~mm}$ dialysis probes, citalopram $(1 \mu \mathrm{M})$ was added to the artificial CSF to increase the detectability of serotonin when probes were implanted within the DRN. Successive 30 min (15 $\mu 1)$ dialysate samples were collected. At the end of the experiment, the probe placement was verified by injection of methylene blue and visual inspection. Animals with a placement of the probe outside the DRN [indicated also by a low extracellular 5-hydroxyindoleacetic acid (5HIAA) concentration; see Discussion] were discarded. The in vitro percentage recoveries of the $1.5 \mathrm{~mm}$ dialysis probes for $\mathrm{DA}$, dihydroxyphenylacetic acid (DOPAC), 5-HT, and 5-HIAA were, respectively (flow rate $=0.5 \mu \mathrm{l} / \mathrm{min}), 20.1 \pm 0.9,21.9 \pm 0.6,23.8 \pm 1.8$, and $18.3 \pm 0.8$ $(n=4$, mean \pm SEM). For the $4.0 \mathrm{~mm}$ dialysis probes these figures were, respectively, $50.6 \pm 1.4,42.2 \pm 1.2,44.7 \pm 0.9$, and $38.7 \pm 0.5$ $(n=4$, mean \pm SEM $)$.

Drugs and reagents. Apomorphine, 5-HT, 5-HIAA, DA, and DOPAC were from Sigma (St. Louis, MO). Quinpirole [(-)LY 171,555] and $( \pm)$ SKF-38393 were from RBI (Natick, MA). $d$-Amphetamine was from the Service of Psychotropic Substances, Ministry of Health, Madrid, Spain. Other materials and reagents were from local commercial sources.

Chromatographic analysis. DA, DOPAC, 5-HT, and 5-HIAA were analyzed by a modification of the HPLC method described in Adell and Artigas (1991). The composition of HPLC eluent was as follows: $0.15 \mathrm{M} \mathrm{NaH}_{2} \mathrm{PO}_{+}, 0.46 \mathrm{~mm}$ octyl sodium sulfate, $0.5 \mathrm{~mm}$ EDTA $(\mathrm{pH}$ 2.8 adjusted with phosphoric acid), and $18 \%$ methanol. The cathecol and indole compounds were separated on a $3 \mu \mathrm{m}$ ODS 2 column (7.5 $\mathrm{cm} \times 0.46 \mathrm{~cm}$; Beckman, CA) and detected amperometrically with a Hewlett Packard 1049 detector, with a limit of detection of $0.5-1 \mathrm{fmol}$ for standard DA and 5-HT (Fig. 2). This HPLC method enabled the simultaneous detection of DA, 5-HT, and their acidic metabolites in the same dialysate samples.

Data analysis. In each experiment, the results (expressed as means \pm SEM) are given as percentage of basal values. The statistical analysis used was the "summary measures" method (Matthews et al., 1990), using the mean of the four values previous to drug administration and the mean of the five values subsequent to drug administration per animal as the summary measures. Post- versus predrug values were compared using Student's paired $t$ test to analyze drug effects. $p$ valucs refer in all cases to these differences.

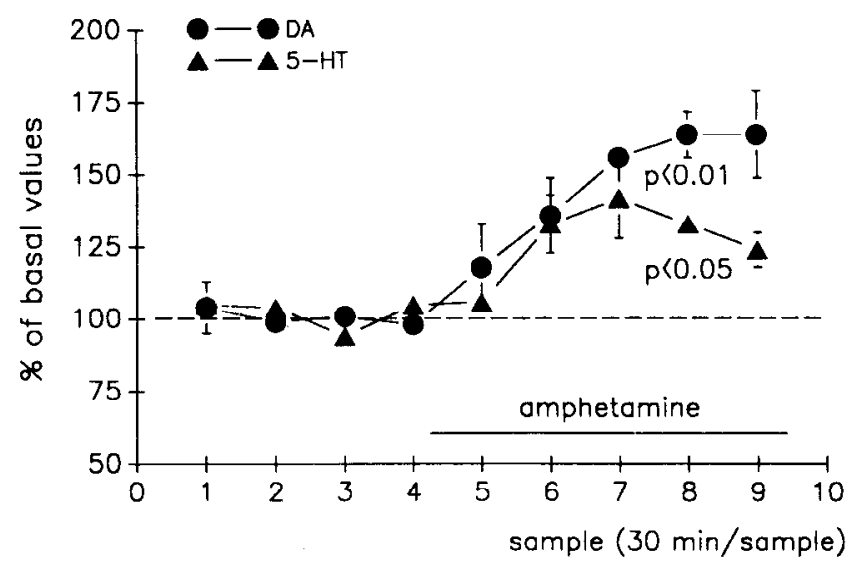

Figure 3. Effect of the intra-DRN infusion of amphetamine $(10 \mu \mathrm{mol} /$ liter) on extracellular concentrations of DA and 5-HT in the DRN. Data are mean $\perp$ SEM values ( $n=4$ in both cases) and are given as percentages of baseline values, determined from the mean of the two values previous to drug infusion. The horizontal line indicates the period of drug infusion.

\section{Results}

Basal dialysate concentrations of DA and 5-HT from the DRN (in the presence of $1 \mu \mathrm{mol} /$ liter citalopram), taken as the mean of the two values preceding drug administration, were as follows (without adjusting for recovery): $1.4 \pm 0.1 \mathrm{nmol} / \mathrm{liter}$ for DA and $9.8 \pm 2.2 \mathrm{nmol} /$ liter for $5-\mathrm{HT}$ (mean $\pm \mathrm{SEM} ; n=4$ and 9 rats, respectively). Basal dialysate concentrations of DA, DOPAC, 5-HT, and 5-HIAA from the striatum, taken as above, were (without adjusting for recovery) $15.9 \pm 2.9 \mathrm{nmol} / \mathrm{liter}$ for DA, $16,429 \pm 2136 \mathrm{nmol} /$ liter for DOPAC, $1.2 \pm 0.2 \mathrm{nmol} /$ liter for 5 -HT, and $1309 \pm 171 \mathrm{nmol} /$ liter for 5 -HIAA (mean $\pm \mathrm{SEM} ; N=12-25$ rats). The occurrence of a neuronal pool of DA within the DRN was revealed by the local infusion of 10 $\mu$ mol/liter amphetamine. This treatment enhanced DA and 5-HT extracellular concentrations (maximal increases $+64 \%$ and $+42 \%$; Student's paired $t$ test: $p<0.01$ and $p<0.05$, respectively) (Fig. 3).

Continuous local infusion of $10 \mu \mathrm{mol} /$ liter of the nonselective DA agonist apomorphine (Fig. 4), the selective DA $D_{1}$-like agonist SKF-38393 (Fig. 5), or the selective DA $D_{2}$-like agonist LY-171555 (quinpirole) (Fig. 6) induced a significant decrease in the striatal extracellular concentrations of DA (maximal reductions: $-76 \%,-54 \%$, and $-62 \%$, respectively; Student's paired $t$ test, $p<0.01$ in all cases) and DOPAC (up to $-30 \%$, $-32 \%$, and $-43 \%$; Student's paired $t$ test, $p<0.05$ for apomorphine effect and $p<0.01$ for SKF-38393 and quinpirole effects). Neither apomorphine, SKF-38393, nor quinpirole significantly altered the striatal extracellular concentrations of 5-HT or 5-HIAA when given locally.

The systemic administration of apomorphine $(2.8 \mu \mathrm{mol} / \mathrm{kg}$, s.c.) induced a significant increase of DRN 5-HT extracellular concentration (maximal increase $+75 \%$; Student's paired $t$ test, $p<0.01$ ) and a significant decrease of 5-HT extracellular concentration in the striatum (up to $-34 \%$; Student's paired $t$ test, $p<0.01$ ) (Fig. 7). In the same dialysate samples, DA concentrations decreased to about $40 \%$ of basal values in the striatum and to undetectable levels in most DRN samples.

To examine the involvement of $5-\mathrm{HT}_{\mathrm{IA}}$ somatodendritic autoreceptors in these opposite changes of extracellular 5-HT in DRN and striatum, we used WAY 100135, a selective antag- 


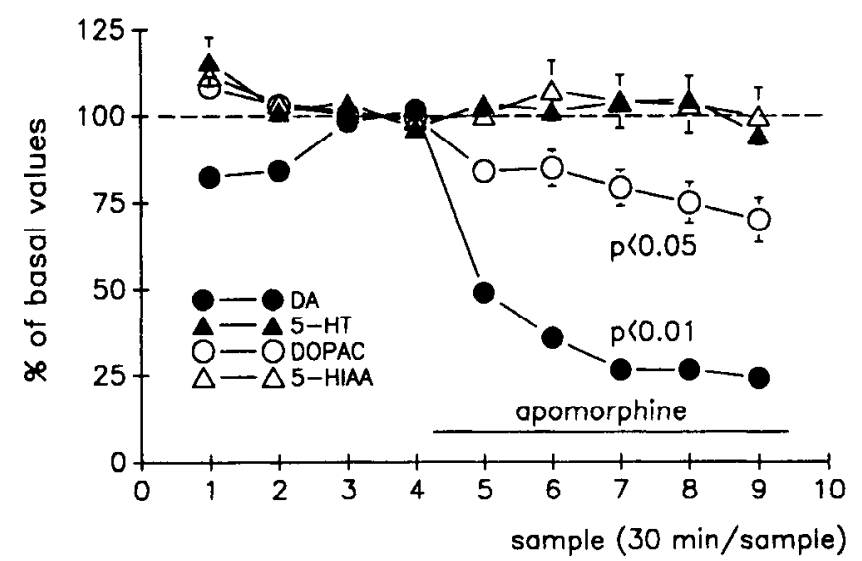

Figure 4. Effect of intrastriatal infusion of the nonselective DA agonist apomorphine $(10 \mu \mathrm{mol} /$ liter $)$ on extracellular concentrations of DA, DOPAC, 5-HT, and 5-HIAA in the striatum. Data are mean \pm SEM values $(n=4)$ and are given as percentages of baseline values, determined from the mean of the two values previous to drug infusion. The horizontal line indicates the period of drug infusion.

onist of 5-HT $\mathrm{HA}_{1 \mathrm{~A}}$ pre- (somatodendritic) and postsynaptic receptors (Fletcher et al., 1993; Routledge et al., 1993). The treatment with WAY 100135 alone $(17.6 \mu \mathrm{mol} / \mathrm{kg}$, s.c.) did not alter dialysate 5-HT or 5-HIAA in the striatum; yet the systemic (subcutaneous) pretreatment with WAY 100135 prevented the reduction of striatal dialysate 5 -HT elicited by apomorphine (Fig. 8).

No overt behavioral effects were observed during local infusion of the different DA agonists, either in the DRN or in the striatum, or after systemic administration of WAY 100135. Stereotypies (mainly sniffing and licking) were observed after systemic administration of apomorphine and were not modified by the previous administration of WAY 100135.

\section{Discussion}

Owing to the development of a new HPLC procedure, we have been able to determine low (0.5-1 fmol) amounts of 5-HT and

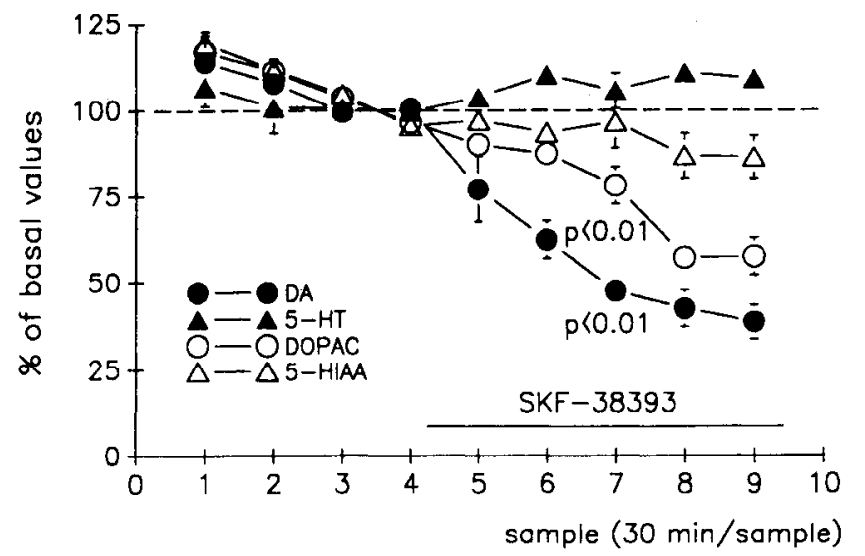

Figure 5. Effect of intrastriatal infusion of the selective DA $\mathrm{D}_{1}$-like agonist SKF-38393 (10 $\mu \mathrm{mol} / \mathrm{liter})$ on extracellular concentrations of DA, DOPAC, 5-HT, and 5-HIAA in the striatum. Data are mean \pm SEM values $(n=4)$ and are given as percentages of baseline values, determined from the mean of the two values previous to drug infusion. The horizontal line indicates the period of drug infusion.

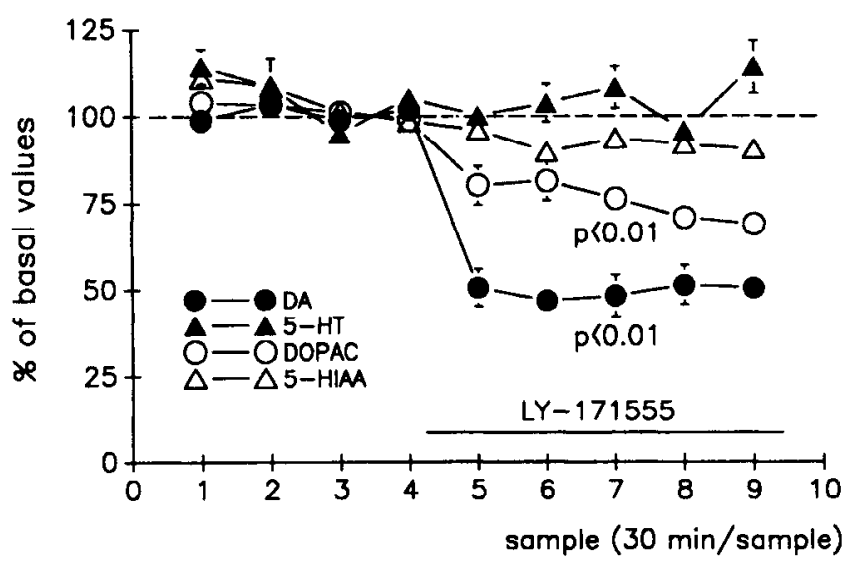

Figure 6. Effect of intrastriatal infusion of the selective $\mathrm{DA} \mathrm{D}_{2}$ agonist LY 171555 (quinpirole) $(10 \mu \mathrm{mol} /$ liter $)$ on extracellular concentrations of DA, DOPAC, 5-HT, and 5-HIAA in the striatum. Data are mean \pm SEM values $(n=4)$ and are given as percentages of baseline values, determined from the mean of the two values previous to drug infusion. The horizontal line indicates the period of drug infusion.

DA in the same dialysate samples from the DRN and striatum. This enabled the simultaneous study of both amines in the same animal. The HPLC method devised is particularly useful for the analysis of DA and 5-HT at very low concentrations, given their short retention times and the consequent increase in detectability. The present results demonstrate for the first time the occurrence of a measurable extracellular concentration of DA in the DRN. The somatodendritic or terminal origin of this DA is unclear, since both dopaminergic terminals from the SN or VTA (Afifi and Kaelber, 1965; Pasquier et al., 1977; Sakai et al., 1977; Lee and Geyer, 1984; Kalén et al., 1988) and DAcontaining neurons within the DRN (Hökfelt et al., 1976; Geffard et al., 1987; Kalén et al., 1988) have been described. The present results cannot clarify this issue, since amphetaminc releases both terminal and somatodendritic DA (Kalivas and Duffy, 1991; Robertson et al., 1991). In any case, the increased extracellular DA after the local administration of amphetamine indicates the existence of a releasable pool of DA close to se-

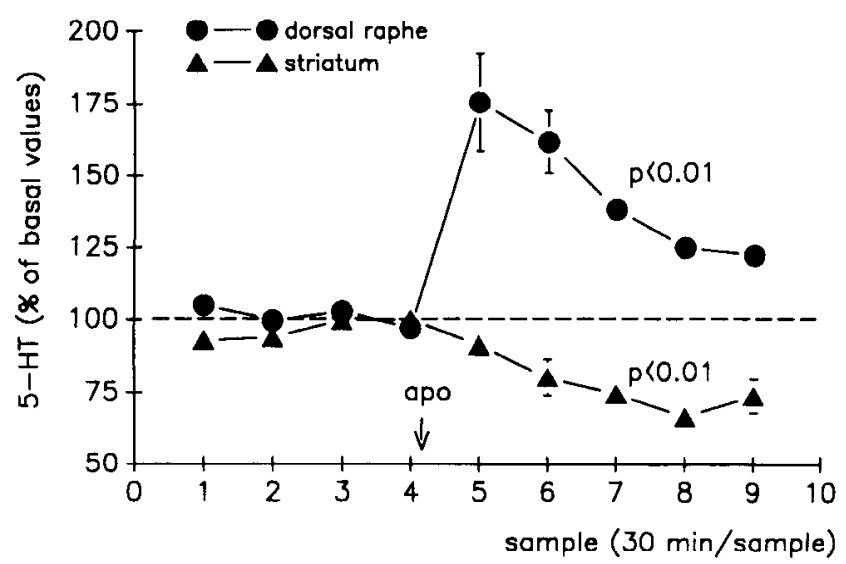

Figure 7. Effect of systemic administration of the nonselective DA agonist apomorphine (apo) $(2.8 \mu \mathrm{mol} / \mathrm{kg})$ on extracellular concentration of 5-HT in the DRN and in the striatum. Data are mean \pm SEM values ( $n=5$ in both cases) and are given as percentages of baseline values, determined from the mean of the two values previous to drug infusion. The arrow indicates the time of apomorphine injection. 


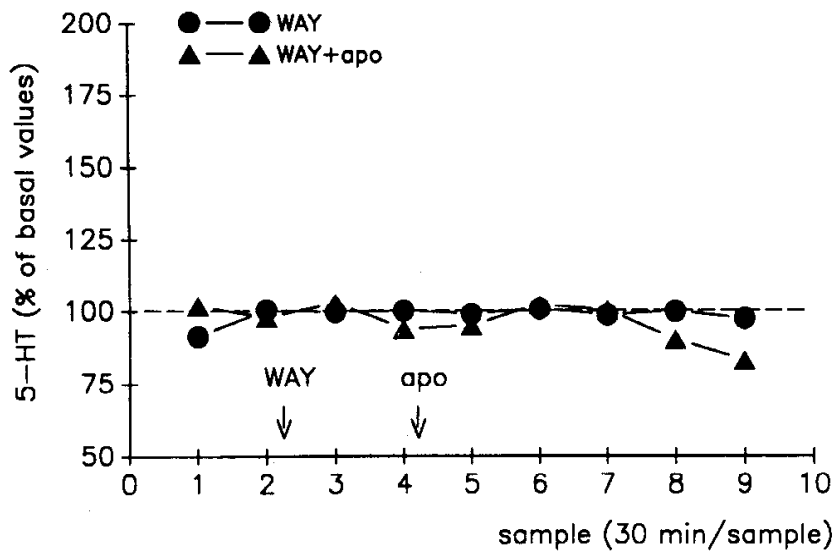

Figure 8. Effect of systemic administration of the 5- $\mathrm{HT}_{1 \mathrm{~A}}$ autoreceptor antagonist WAY $100135(W A Y)(17.6 \mu \mathrm{mol} / \mathrm{kg}$, s.c.) alone and together with the nonselective DA agonist apomorphine (apo) $(2.8 \mu \mathrm{mol} / \mathrm{kg}$, s.c.) on the extracellular concentration of 5-HT in the striatum. Data are mean \pm SEM values ( $n=4$ in both cases) and are given as percentages of baseline values, determined from the mean of the two values previous to apomorphine administration. The arrows indicate the times of drug administration.

rotonergic cell bodies and dendrites in the DRN, a nucleus that contains a substantial density of $\mathrm{DA}_{2}$-like receptors (Bouthenet et al., 1987; Palacios and Pazos, 1987). This suggests that the DA-5-HT interaction found within the DRN in this and a previous study (Ferré and Artigas, 1993) may be physiologically relevant for the control of ascending serotonergic pathways. 5-HT extracellular concentration was also increased by the local application of amphetamine in the DRN. This is in accordance with data in the literature indicating an in vivo releasing action of amphetamine on 5-HT, as measured by microdialysis (Parada et al., 1988), although an indirect action caused by the increased DA may also contribute.

The basal concentration of extracellular 5-HT was not dependent on a precise position of the probe in the DRN, as observed in rats with an incorrect placement (not included in the study). In contrast, a high extracellular 5-HIAA concentration was a good indicator of the location of the probe within the boundaries of the DRN. This agrees with data showing that the basal extracellular concentration of 5-HT, as measured with microdialysis, is independent to a large extent on the density of innervation, thus reflecting the equilibrium between release and reuptake (Adell et al., 1991; Jackson and Abercrombie, 1992). However, since 5-HIAA lacks any reuptake system, its extracellular concentration is determined by its tissue content, higher in the raphe nuclei than in other brain areas (Adell et al., 1991).

The results obtained in this study extend previous observations indicating that (1) dopaminergic transmission increases extracellular 5-HT in the DRN, presumably through $\mathrm{D}_{2}$-like receptors (Ferré and Artigas, 1993), and (2) the increased availability of 5-HT at somatodendritic 5-HT ${ }_{1 A}$ autoreceptors results in decreases of terminal serotonergic release (Becquet et al., 1990; Adell and Artigas, 1991).

In agreement with data in the literature, the striatal application of dopaminergic agonists induced a marked decrease of DA extracellular concentration. Thus, the local infusion of 10 $\mu \mathrm{mol} / \mathrm{liter}$ of the nonselective DA receptor agonist apomorphine, the selective DA $D_{1}$-like receptor agonist SKF-38393, or the selective $\mathrm{DA}_{2}$-like receptor agonist quinpirole induced a strong and sustained decrease of striatal DA extracellular concentration. Similarly, DOPAC extracellular concentrations were significantly decreased by the local infusion of DA agonists. These reductions are most probably due to the activation of $\mathrm{D}_{2}$ like release-inhibiting autoreceptors (by apomorphine and quinpirole) or postsynaptic $D_{1}$-like receptors (by apomorphine and SKF 38393) located in striatonigral GABA neurons that control the activity of nigrostriatal dopaminergic neurons (Imperato and Di Chiara, 1988; Reid et al., 1990; Fuxe et al., 1992).

In contrast, striatal 5-HT and 5-HIAA extracellular concentrations in the same animals were unchanged after a dose $(10$ $\mu \mathrm{mol} /$ liter) of apomorphine and quinpirole that increased 5-HT concentration in DRN (Ferré and Artigas, 1993). Hence, whereas 5-HT promotes DA striatal release when applied locally (Blandina et al., 1989; Benloucif and Galloway, 1991), the activation of dopaminergic $D_{1}$-like and $D_{2}$-like receptors in the striatum does not result in local changes of 5-HT release. Clearly, this indicates an interaction of serotonergic transmission on terminal (striatal) dopaminergic function but not the opposite. Yet the local and systemic administration (this study) of the DA agonist apomorphine increased raphe extracellular 5-HT, an effect mediated by $\mathrm{D}_{2}$-like receptors in the DRN (Ferre and Artigas, 1993). An increased intra- and extracellular concentration of 5-HT in DRN, as measured by a histofluorescence method, has already been reported after the systemic treatment with apomorphine (Lee and Geyer, 1984). However, these authors described a 1:3 ratio for extra- versus intracellular 5-HT, whereas it is widely accepted that this ratio is over $1: 1000$ for most neurotransmitters (Westerink et al., 1987) in different brain areas, including 5-HT in the raphe nuclei (Adell et al., 1991). Therefore, the relationship of the present in vivo results with the increased extracellular histofluorescence found by these authors is unclear. Also, apomorphine was reported to increase slightly $(+12 \%)$ the striatal (but not the hippocampal) total tissue content of 5-HT (Lee, 1987), whereas a reduction of striatal extracellular 5-HT has been found herein. This discrepancy is likely to be due to the measurement of active (extracellular) and reserve (intracellular) pools when total tissue concentrations are involved. In contrast, only active pools of the transmitter are measured with the microdialysis technique.

The opposite changes of extracellular 5-HT in DRN (increase) and striatum (decrease) induced by the systemic administration of apomorphine suggest that DA may inhibit the activity of ascending serotonergic pathways originating in the DRN via an incrcase of the extracellular concentration of 5-HT in DRN. Presumably, the reduction of striatal extracellular 5-HT results from the activation of somatodendritic $5-\mathrm{HT}_{1 \mathrm{~A}}$ receptors located in DRN (Pazos and Palacios, 1985; Vergé et al., 1986; Sotelo et al., 1990) secondary to the increase of 5-HT induced by apomorphine. Extracellular concentration of 5-HT in the midbrain raphe region is in the low nanomole/liter range (Adell et al., 1993), close to its affinity for $5-\mathrm{HT}_{1 \mathrm{~A}}$ receptors (Pedigo et al., 1981). Hence, increases of 5-HT availability in the vicinity of serotonergic cell bodies and dendrites may result in decreased terminal synthesis and/or release, as shown previously (Becquet et al., 1990; Adell and Artigas, 1991). Interestingly, the reduction of striatal extracellular 5-HT appears to be delayed with respect to the increase produced in DRN. This seems to be at variance with the fact that terminal 5-H' release increases shortly after the electric stimulation of the DRN (Sharp et al., 1989b, 1990), indicating a firing-coupled relcasc. Howcver, the maximal reductions of terminal 5 -HT output in frontal cortex or 
striatum, two areas receiving a prominent DRN innervation, after the local (intraraphe) application of direct (8-OH-DPAT; Bonvento et al., 1992) and indirect (clomipramine; Adell and Artigas, 1991) 5-HT, agonists are delayed with respect to the drug application. This delay has also been observed by Becquet et al. (1990). These authors found a decreased ${ }^{3} \mathrm{H}-5$-HT release (newly synthesized from superfused ${ }^{3} \mathrm{H}$-tryptophan) in the caudate of cats during the perfusion of a 5-HT-releasing agent in the DRN. The reduced ${ }^{3} \mathrm{H}-5$-HT release in striatum persisted at least for $1 \mathrm{hr}$ after the withdrawal of the 5-HT-releasing agent in DRN, a time when 5-HT release in DRN had almost regained normal levels. This is indicative that the diminished 5-HT terminal release may not be an immediate consequence of the suppression of firing at the somatodendritic level by 5-HT or

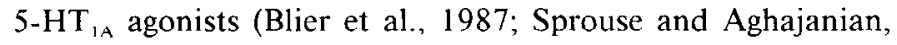
1987; Sinton and Fallon, 1988) and points toward a reduction of a terminal 5 -HT releasable pool as a likely cause of the decreased 5-HT extracellular concentration in terminal areas. Indeed, 5-HT ${ }_{1 A}$ agonists markedly reduce terminal 5-HT synthesis when applied locally in the DRN (Hutson et al., 1989; Invernizzi et al., 1991), the striatum and prefrontal cortex being the two most sensitive brain areas (Invernizzi et al., 1991).

That the reduction of extracellular 5-HT in the striatum following systemic administration of apomorphine may be secondary to the increase of 5-HT in the DRN is also supported by the lack of a local action of the dopaminergic agonists (see Figs. 4-6) and the blockade of the effect with the systemic treatment with WAY 100135, a selective antagonist of pre- (somatodendritic) and postsynaptic 5-IIT ${ }_{1 A}$ receptors (Fletcher et al., 1993; Routledge et al., 1993). At the dose used (17.6 $\mu \mathrm{mol} /$ $\mathrm{kg}$ ), this compound prevents the reduction of hippocampal 5-HT release induced by the occupation of somatodendritic 5- $\mathrm{HT}_{1 \mathrm{~A}}$ receptors by the selective agonist $8-\mathrm{OH}$-DPAT (Routledge et al., 1993; Romero et al., unpublished observations). The injection of WAY 100135 alone did not modify the basal 5-HT output in striatum. This agrees with previous reports indicating that $5-\mathrm{HT}_{1 \mathrm{~A}}$ autoreceptors in the DRN are not tonically activated (Innis and Aghajanian, 1987; Trulson and Frederickson, 1987; Becquet et al., 1990).

Interestingly, Stern et al. (1981) found an almost complete suppression of unit activity in DRN following electrical stimulation of the substantia nigra that, unlike that obtained by stimulation of the lateral habenula, could not be blocked by picrotoxin. This indicates the existence of a functional inhibitory nigro-raphe pathway not involving GABAergic interneurons in the DRN. The results obtained in the present and previous (Ferré and Artigas, 1993) studies support the view that the excess 5-HT in the interstitial space in the DRN after dopaminergic $D_{2}$-like activation may participate in the suppression of unit activity found previously (Stern et al., 1981), through the hyperpolarization of serotonergic cells mediated by the opening of 5-HT ${ }_{1 A}$-gated $\mathrm{K}^{+}$channels (Innis and Aghajanian, 1987; HajDahmane et al., 1991).

In summary, the present results provide neurochemical support for an inhibitory dopaminergic control of ascending serotonergic pathways, mediated at the somatodendritic level (in DRN) through increases of the extracellular 5-HT concentration. The lack of a local action of dopaminergic agents precludes a DA-mediated control of striatal 5-HT release at the terminal level. The origin of the dopaminergic afferents responsible for these effects is uncertain and must await further studies.

\section{References}

Adell A, Artigas F (1991) Differential effects of clomipramine given locally or systemically on extracellular 5-hydroxytryptamine in raphe nuclei and frontal cortex. An in vivo microdialysis study. Naunyn Schmiedebergs Arch Pharmacol 343:237-244.

Adell A, Carceller A, Artigas F (1991) Regional distribution of extracellular 5-hydroxytryptamine and 5-hydroxyindoleacetic acid in the brain of freely moving rats. J Neurochem 56:709-712.

Adell A, Carceller A, Artigas F (1993) In vivo brain dialysis study of the somatodendritic release of serotonin in the raphe nuclei of the rat. Effects of 8-hydroxy-2-(di-n-propylamino)tetralin. J Neurochem 60:1673-1681.

Afifi A, Kaelber WW (1965) Efferent connections of the substantia nigra in the cat. Exp Neurol 11:474-482.

Aghajanian GK, Sprouse JS, Rasmussen K (1987) Physiology of the midbrain serotonin system. In: Psychopharmacology: the third gen eration of progress (Meltzer HY, ed), pp 141-149. New York: Raven.

Alexander GE, Crutcher MD (1990) Functional architecture of basal ganglia circuits: neural substrates of parallel processing. Trends Neurosci 13:266-271.

Becquet D, Faudon M, Hery F (1990) The role of serotonin release and autoreceptors in the dorsalis raphe nucleus in the control of serotonin release in the cat caudate nucleus. Neuroscience 39:639647.

Benloucif S, Galloway MP (1991) Facilitation of dopamine release in vivo by serotonin agonists: studies with microdialysis. Eur J Pharmacol 200:1-8.

Björklund A, Lindvall O (1984) Dopamine-containing systems in the CNS. In: Handbook of chemical neuroanatomy, $\mathrm{Vol} 2$, Classical neurotransmitters and transmitter receptors in the CNS (Björklund A, Hökfelt T, eds), pp 55-122. Elsevier: Amsterdam.

Blandina P, Goldfarb J, Craddock-Royal B, Peter Green J (1989) Release of endogenous dopamine by stimulation of 5-hydroxytryptamine ${ }_{3}$ receptors in rat striatum. J Pharmacol Exp Ther 251:803-809.

Blier P, De Montigny C (1987) Modification of 5-HT neuron properties by sustained administration of the 5 -HTla agonist gepirone: electrophysiological studies in the rat brain. Synapse 1:470-480.

Bonvento G, Scatton B, Claustre Y, Rouquier L (1992) Effect of local injection of 8-OH-DPAT into the dorsal or median raphe nuclei on extracellular levels of serotonin in serotonergic projection areas in the rat brain. Neurosci Lett 137:101-104.

Bouthenet ML, Martres MP, Sales N, Schwartz JC (1987) A detailed mapping of dopamine D-2 receptors in rat central nervous system by autoradiography with [125I]iodosulpiride. Neuroscience 20:117-155.

Chen J, van Praag HM, Gardner EL (1991) Activation of 5-HT $\mathrm{HT}_{3}$ receptor by 1 -phenylbiguanide increases dopamine release in the rat nucleus accumbens. Brain Res 543:354-357.

Cortés R, Mengod G, Celada P, Artigas F (1993) p-Chlorophenylalanine increases tryptophan-5-hydroxylase mRNA levels in the rat dorsal raphe: a time course study using in situ hybridization. J Neurochem 60:761-764.

Cross AJ (1988) Serotonin in neurodegenerative disorders. In: Neuronal serotonin (Osborne NN, Hamon M, eds), pp 231-253. New York: Wiley.

Dahlström A, Fuxe K (1964) Evidence for the existence of monoamine-containing neurons in the central nervous system. 1 . Demonstration of monoamines in the cell bodies of brainstem neurons. Acta Physiol Scand 232:1-55

Ferré S, Artigas F (1993) Dopamine $\mathrm{D}_{2}$ receptor-mediated regulation of serotonin extracellular concentration in the dorsal raphe nucleus of freely moving rats. J Neurochem 61:772-775.

Fletcher A, Bill DJ, Bill SJ, Cliffe IA, Dover GM, Forster EA, Haskins JT, Jones D, Mansell HL, Reilly Y (1993) WAY 100135: a novel, selective antagonist at presynaptic and postsynaptic $5-\mathrm{HT}_{\mathrm{IA}}$ receptors. Eur J Pharmacol 237:283-291.

Fuxe K, O'Connor WT, Antonelli T, Osborne PG, Tanganelli S, Agnati LF, Ungerstedt U (1992) Evidence for a substrate of neuronal plasticity based on pre- and postsynaptic neurotensin-dopamine receptor interactions in the neostriatum. Proc Natl Acad Sci USA 89:55915595.

Geffard M, Tuffet S, Mons N, Chagnaud J-L (1987) Simultaneous detection of indolamines and dopamine in rat dorsal raphe nuclei using specific antibodies. Histochemistry 88:61-64.

Guan X-M, McBride W (1989) Serotonin microinfusion into the ven- 
tral tegmental area increases accumbens dopamine release. Brain Res Bull 23:541-547.

Haj Dahmane S, Hamon M, Lanfumey L (1991) K+ channel and 5 -hydroxytryptamine ${ }_{1 \mathrm{~A}}$ autoreceptor interactions in the rat dorsal raphe nucleus: an in vitro electrophysiological study. Neuroscience 41: 495-505.

Herve DII, Pickel VM, Joh TH, Bcaudct A (1987) Scrotonin axon terminals in the ventral tegmental area of the rat: fine structure and synaptic input to dopaminergic neurons. Brain Res 435:71-83.

Hjorth S, Magnusson T (1988) The 5- $\mathrm{HT}_{1 \mathrm{~A}}$ receptor agonist, 8-OHDPAT, preferentially activates cell body autoreceptors in rat brain in vivo. Naunyn Schmiedebergs Arch Pharmacol 338:463-471.

Hökfelt T, Johansson O, Fuxe K, Goldstein M, Park D (1976) Immunohistochemical studies on the localization and distribution of monoamine neuron systems in the rat brain. I. Tyrosine hydroxylase in mes- and diencephalon. Med Biol 54:427-453.

Hoyer D (1990) Serotonin 5-HT, $5-\mathrm{HT}_{4}$ and $5-\mathrm{HT}_{M}$ receptors. Neuropsychopharmacology 3:371-383.

Hutson PH, Sarna GS, O'Connell MT, Curzon G (1989) Hippocampal 5-HT synthesis and release in vivo is decreased by infusion of 8-OHDPAT into the nuclcus raphe dorsalis. Neurosei Lett 100:276280.

Imperato A, Di Chiara G (1988) Effects of locally applied D-1 and D-2 receptor agonists and antagonists studied with brain dialysis. Eur J Pharmacol 156:385-393.

Innis RB, Aghajanian GK (1987) Pertussis toxin blocks 5-HT ${ }_{1 \mathrm{~A}}$ and $G A B A_{13}$ receptor-mediated inhibition of serotonergic neurons. Eur J Pharmacol 143:195-204

Innis RB, Nestler EJ, Aghajanian GK (1988) Evidence for G protein mediation of serotonin- and GABA B-induced hyperpolarization of rat dorsal raphe neurons. Brain Res 459:27-36.

Invernizzi R, Carli M, Di Clemente A, Samanin R (1991) Administration of 8-hydroxy-2-(di- $n$-propylamino)tetralin in raphe nuclei dorsalis and medianus reduces serotonin synthesis in the rat brain: differences in potency and regional sensitivity. J Neurochem 56:243247.

Jackson D, Abercrombie ED (1992) In vivo neurochemical evaluation of striatal serotonergic hyperinnervation in rats depleted of dopamine at infancy. J Neurochem 58:890-897.

Jacobs BL, Azmitia EC (1992) Structure and function of the brain serotonin system. Physiol Rev 72:165-229.

Kalén P, Skagerberg G, Lindvall O (1988) Projections from the ventral tegmental area and mesencephalic raphe to the dorsal raphe nucleus in the rat. Exp Brain Res 73:69-77.

Kalivas PW, Duffy P (1991) A comparison of axonal and somatodendritic dopamine release using in vivo dialysis. J Neurochem 56: 961-967.

Lee EHY (1987) Additive effects of apomorphine and clonidine on scrotonin ncurons in the dorsal raphe. Life Sci 40:635-642.

Lee EHY, Geyer MA (1984) Dopamine autoreceptor mediation of the effects of apomorphine on serotonin neurons. Pharmacol Biochem Behav 21:301-311.

Matthews JNS, Altman DG, Campbell MJ, Royston P (1990) Analysis of serial measurements in medical research. Br Med J 300:230-235.

McKenna DJ, Peroutka SJ (1990) Neurochemistry and neurotoxicity of 3,4-methylenedioxyamphetamine (MDMA, "Ecstasy"). J Neurochem $54: 14-22$.

Meltzer HY (1992) The importance of serotonin-dopamine interactions in the action of clozapine. Br J Psychiatry 160:22-29.

Nedergaard S, Bolam JP, Greenfield SA (1988) Facilitation of a dendritic calcium conductance by 5-hydroxytryptamine in the substantia nigra. Nature 333:174-177.

O'Hearn E, Molliver ME (1984) Organization of raphe cortical projections in rat: a quantitative retrograde study. Brain Res Bull 13: 709-726.

Palacios JM, Pazos A (1987) Visualization of dopamine receptors: a progress review. In: Dopamine receptors (Creese I, Fraser C, eds), pp 175-197. New York: Liss.

Parada M, Hernandez L, Schwartz D, Hoebel BG (1988) Hypothalamic infusion of amphetamine increases serotonin, dopamine and norepinephrine. Physiol Behav 44:607-610.

Parsons LH, Justice JB (1993) Perfusate serotonin increases extracellular dopamine in the nucleus accumbens as measured by in vivo microdialysis. Brain Res 606:195-199.

Pasquier DA, Kemper TL, Forbes WB, Morgane PJ (1977) Dorsal raphe, substantia nigra and locus coeruleus: interconnections with each other and the neostriatum. Brain Res Bull 2:323-339.

Paxinos G, Watson C (1982) The rat brain in stereotaxic coordinates. Sydney: Academic.

Pazos A, Palacios JM (1985) Quantitative autoradiographic mapping of serotonin receptors in the rat brain. I. Serotonin, receptors. Brain Res 346:205-230.

Pazos A, Cortés R, Palacios JM (1985) Quantitative autoradiographic mapping of serotonin receptors in the rat brain. II. Serotonin-2 receptors. Brain Res 346:231-249.

Pedigo NW, Yamamura HI, Nelson DL (1981) Discrimination of multiple $\left[{ }^{3} \mathrm{H}\right] 5$-hydroxytryptamine binding sites by the neuroleptic spiperone in rat brain. $J$ Neurochem 36:220-226.

Reid MS, O'Connor WT, Herrera-Marschitz M, Ungerstedt U (1990) The effects of intranigral GABA and dynorphin A injections on striatal dopamine and GABA release: evidence that dopamine provides inhibitory regulation of striatal GABA neurons via $D$, receptors. Brain Res 519:255-260.

Robertson GS, Damsma G, Fibiger HC (1991) Characterization of dopamine release in the substantia nigra by in vivo microdialysis in frecly moving rat. J Ncurosci 11:2209-2216.

Routledge C, Gurling J, Wright IK, Dourish CT (1993) Neurochemical profile of the selective and silent $5-\mathrm{HT}_{1 \mathrm{~A}}$ receptor antagonist WAY 100135: an in vivo microdialysis study. Eur J Pharmacol 239:195202.

Sakai K, Salvert D, Touret M, Jouvet M (1977) Afferent connections of the nucleus raphe dorsalis in the cat as visualized by horseradish peroxidase technique. Brain Res 137:11-35.

Scatton B, Javoy-Agid F, Montfort JC, Agid Y (1984) Neurochemistry of monoaminergic neurons in Parkinson's disease. In: Catecholamines: neuropharmacology and central nervous system - therapeutic aspects (Usdin E, Carlsson A, Dahlström A, Engel J, eds), pp 43-52. New York: Liss.

Sharp T, Bramwell SR, Grahame-Smith DG (1989a) 5-HT, agonists reducc 5-hydroxytryptamine rclease in rat hippocampus in vivo as determined by brain microdialysis. Br J Pharmacol 96:283-290.

Sharp T, Bramwell SR, Clark D, Grahame-Smith DG (1989b) In vivo measurement of extracellular 5-hydroxytryptamine in hippocampus of the anaesthetized rat using microdialysis: changes in relation to 5-hydroxytryptaminergic neuronal activity. J Neurochem 53:234-240.

Sharp T, Bramwell SR, Grahame-Smith DG (1990) Release of endogenous 5-hydroxytryptamine in rat ventral hippocampus evoked by electrical stimulation of the dorsal raphe nucleus as detected by microdialysis: sensitivity to tetrodotoxin, calcium and calcium antagonists. Neuroscience 39:629-637.

Sinton CM, Fallon SL (1988) Electrophysiological evidence for a functional differentiation between subtypes of the 5-HT1 receptor. Eur J Pharmacol 157:173-181.

Sotelo C, Chollcy B, El Mestikawy S, Gozlan H, Hamon M (1990) Direct immunohistochemical evidence of the existence of $5-\mathrm{HT}_{1 \mathrm{~A}}$ autoreceptors on serotoninergic neurons in the midbrain raphe nuclei. Eur J Neurosci 2:1144-1154.

Sprouse JS, Aghajanian GK (1987) Electrophysiological responses of serotoninergic dorsal raphe neurons to $5-\mathrm{HT}_{1 \mathrm{~A}}$ and $5-\mathrm{HT}_{1 \mathrm{~B}}$ agonists. Synapse 1:3-9.

Sprouse JS, Aghajanian GK (1988) Responses of hippocampal pyramidal cells to putative serotonin 5-HT $\mathrm{T}_{1 \mathrm{~A}}$ and 5 - $\mathrm{HT}_{1 \mathrm{~B}}$ agonists: a comparative study with dorsal raphe neurons. Neuropharmacology 27: 707-715.

Stern WC, Johnson A, Bronzino JD, Morgane PJ (1981) Neuropharmacology of the afferent projections from the lateral habenula and substantia nigra to the anterior raphe in the rat. Neuropharmacology 20:979-989.

Tamminga CA, Gerlach J (1987) New neuroleptics and experimental antipsychotics in schizophrenia. In: Psychopharmacology: the third generation of progress (Meltzer HY, ed), pp 1129-1140. New York: Raven.

Trulson ME, Frederickson CJ (1987) A comparison of the electrophysiological and pharmacological properties of serotonin-containing neurons in the nucleus raphe dorsalis, raphe medianus and raphe pallidus recorded from mouse brain slices in vitro: role of autoreceptors. Brain Res Bull 18:179-190.

Van der Kooy D, Hattori T (1980) Dorsal raphe cells with collateral projections to the caudate-putamen and substantia nigra: a fluorescent retrograde double labelling study in the rat. Brain Res 186:1-7. 
Vergé D, Daval G, Marcinkiewicz M, Patey A, El Mestikawy S, Grozlan H, Hamon M (1986) Quantitative autoradiography of multiple 5-HT, receptor subtypes in the brain of control or 5,7-dihydroxytryptaminetreated rats. I Neurosci 6:3474-3482.

Waeber C, Dietl MM, Hoyer D, Palacios JM (1989) 5-HT, receptors in the vertebrate brain regional distribution examined by autoradiography. Naunyn Schmiedebergs Arch Pharmacol 340:486-494.

Waeber C, Schoeffter P, Hoyer D, Palacios JM (1990) The serotonin 5-HT in receptor: a progress review. Neurochem Res 15:567-582.
Westerink BHC, Damsma G, Rollema H, de Vries JB, Horn As (1987) Scope and limitations of in vivo brain dialysis: a comparison of its application to various neurotransmitter systems. Life Sci 41:17631776.

Wicklund L, Leger L, Persson M (1981) Monoamine cell distribution in the cat brain. A fluorescence histochemical study with quantification of indolaminergic and locus coeruleus cell groups. J Comp Neurol 203:613-647. 